experimental range of quality factors was from I to $10^{8}$. This scale is divided into intervals, and in each interval one plots separately the per cent of recrystallized and unrecrystallized samples (Fig. 2). Good samples are found only among the recrystallized samples. Furthermore, a careful examination of the specimens indicates that the quality factor and the absolute intensity of the photocurrent are the highest in the samples with the largest and most perfect crystals.

Financial support for this work was provided by the Union Carbide Corporation.

\section{J. M. GILLES}

J. Van Cakenberghe

Buropean Research Associates s.a.,

95 rue Gatti de Gamond,

Brussels. June 27.

'Aitchinson, R. E., Nature, 167, 812 (1951).

'Nelson, R. C., J. Opt. Soc. Amer., 45, 774 (1955).

${ }^{3}$ Forgue, S. V., Goodrich, R. R., and Cope, A. D., R.C.A. Rev., 12, 335 (1951).

${ }^{4}$ Veith, M., C.R. Acad. Sci., Paris, 236, 947 (1950).

\section{Identity of lons in Some Flames}

Some results reported in a previous communication in Nature ${ }^{1}$ have shown the possibility of mass spectrometric identification of the ions present in some flames. More results have now been obtained which suggest a comparison between different kinds of flames burning at a pressure of about $10 \mathrm{~mm}$. mercury instead of the pressure of $40 \mathrm{~mm}$. chosen in our earlier experiments.

The bare determination of the mass number of the observed peaks is not sufficient to identify unambiguously the corresponding ions; however, by burning partially deuterated fuel, the hydrogen content of the ions can be carefully checked.

The ions described here are given in sequence of decreasing abundance. The figures under the heading "Hydrogen content" are the number of hydrogen atoms contained in each ion; these figures are, of course, one unit less than the number of peaks into which the original single peak is split when partially deuterated fuel is burned. Furthermore, it was shown that the relative intensity of the split peaks corresponds fairly well to what can be estimated from the percentage of deuterium in the fuel molecule. All results reported here (Table 1) concern flames which are being propagated in undiluted mixtures rich in fuel (except when otherwise stated); the flames were kept as near as possible to the hole through which the ions are extracted.

From these results, the following conclusions may be derived: (1) There seems to be a tendency for $\mathrm{H}+$ to be attached to polar molecules such as $\mathrm{H}_{2} \mathrm{O}, \mathrm{NH}_{3}$ and HCN. (2) $\mathrm{NH}_{4}+$ can be formed as soon as the flame is propagated in a mixture where nitrogen is a part of the fuel or of the oxidizer molecule. (3) Once too great an amount of NO is present in the burned gases, most of the ions are NO+. This is probably due to the lower ionization energy of NO (charge transfer in the flame front).

This last point is confirmed by the following observation: peak intensities decrease when the ions are sampled at a larger distance ahead of the flame : the rate of this decrease is not the same for all ions and, in some cases, one observes first for $\mathrm{NO}+$ a slight increase after which, because of recombination, the normal decrease is observed.

We have not systematically extended our investigations beyond 45 mass units. Some higher masses

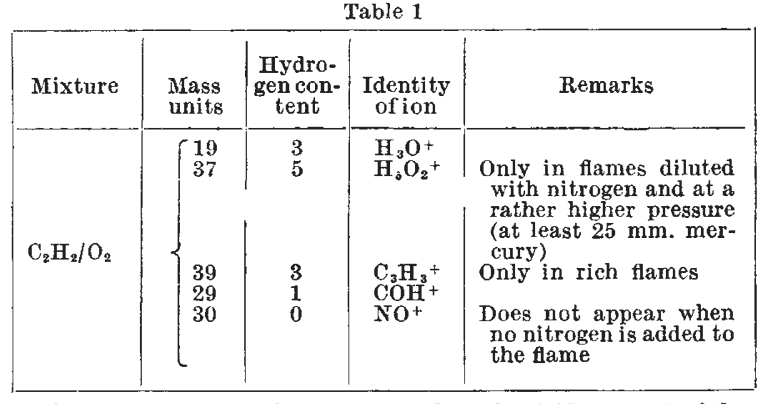

The masses 19,37 and 39 correspond to about 95 per cent of the total ion concentration.

Very weak peaks are noticed at masses 13, 14, 17, 18, 24, 26, 28 and 43 (less than $0 \cdot 1$ per cent).

\begin{tabular}{|c|c|c|c|c|}
\hline $\mathrm{C}_{2} \mathrm{H}_{2} / \mathrm{N}_{2} \mathrm{O}$ & $\left\{\begin{array}{l}30 \\
18 \\
19 \\
28 \\
39 \\
29 \\
43\end{array}\right.$ & $\begin{array}{l}0 \\
4 \\
3 \\
2 \\
3 \\
1 \\
? \\
?\end{array}$ & $\begin{array}{l}\mathrm{NO}^{+} \\
\mathrm{NH}_{4}^{+} \\
\mathrm{H}_{8} \mathrm{O}^{+} \\
\mathrm{H}_{8} \mathrm{CN}^{+} \\
\mathrm{C}_{8} \mathrm{H}_{8}^{+} \\
\mathrm{COH}^{+} \\
\quad ?\end{array}$ & $\begin{array}{l}\text { At least } 90 \text { per cent } \\
\text { Only in rich mixtures } \\
\text { Too weak to check } \\
\text { hydrogen content }\end{array}$ \\
\hline
\end{tabular}

Very weak peaks at masses $26,31,41,44$ (less than $0 \cdot 1$ per cent).

\begin{tabular}{|c|c|c|c|c|}
\hline $\mathrm{CH}_{4} / \mathrm{O}_{2}$ & $\begin{array}{l}19 \\
29\end{array}$ & $\begin{array}{l}3 \\
1\end{array}$ & $\frac{\mathrm{H}_{8} \mathrm{O}^{+}}{\mathrm{HOH}^{+}}$ & Only about 1 per cent \\
\hline $\begin{array}{l}\mathrm{C}_{2} \mathrm{H}_{2} / \mathrm{O}_{2} \\
\text { with about } \\
1 \text { per cent } \\
\mathrm{NH}_{3} \\
\mathrm{C}_{2} \mathrm{H}_{2} / \mathrm{O}_{2} \\
\text { with about } \\
2 \text { per cent } \\
\mathrm{HCN}\end{array}$ & \multicolumn{4}{|c|}{$\begin{array}{l}\text { More or less the same mass spectrum as in the } \\
\text { case of } \mathrm{C}_{2} \mathrm{H}_{2} / \mathrm{N}_{2} \mathrm{O} \text { flames; however, the } \mathrm{NO}^{+} \\
\text {peak is relatively weaker. } \\
\text { The ratio } \mathrm{H}_{2} \mathrm{CN} / \mathrm{NO}^{+} \text {is about the same in both } \\
\text { cases, } \mathrm{NH}_{4}^{+} \text {is less important with the addition } \\
\text { of } \mathrm{HCN} \text { than of } \mathrm{NH}_{3} \text {. }\end{array}$} \\
\hline
\end{tabular}

are reported by P. F. Knewstubb and T. M. Sugden ${ }^{2}$; in our low-pressure flames the corresponding peaks are absent or much weaker than those observed by these authors on flames burning at atmospheric pressure.

This work has been sponsored in part by the Aeronautical Research Laboratory Wright Air Development Center of the Air Research and Development Command, U.S. Air Force, through its European Office (Contract No. $A F 61(514)-1099$.

J. DeCkers

Université de Louvain.

A. van Tiggelen

Nature, 181, 1460 (1958).

2 Nature, 181, 474 and 1261 (1958).

\section{Gas Chromatograph as a Methanometer in the Coal Industry}

GAS-SOLID chromatography has now found acceptance for the determination of hydrogen in mine atmospheres. The instruments developed for this purpose also give a complete separation of methane. An investigation was therefore undertaken to determine the possibility of using the existing instruments for routine or emergency estimation of methane in cases where the higher accuracy of the Haldane apparatus was not necessary, or when the use of volumetric combustion methods was not practicable. For routine use the gas chromatograph has the advantage of speed and specificity, and moreover it can be operated by semi-skilled personnel.

The apparatus used in these experiments was the gas chromatograph for the determination of hydrogen in mine airs, developed by the National Coal Board (North-Western Division) for use in its Area 